\title{
Water use at Luxor, Egypt: consumption analysis and future demand forecasting
}

\author{
Ayman A. Ahmed • Graham E. Fogg • \\ Mohsen A. Gameh
}

Received: 14 September 2013/Accepted: 13 December 2013/Published online: 24 December 2013

(C) Springer-Verlag Berlin Heidelberg 2013

\begin{abstract}
Water resources in Egypt are becoming scarce and the demand for clean drinking water supply is one of the most important priorities of the Egyptian government in recent years. Analyzing water use and future demand forecasting is a primitive clue for water demand management. Water in Luxor is used for agricultural, residential, institutional, commercial, and touristic purposes. The results of water use analysis indicated that for the time period from 1983 to 2012, agriculture is the highest consumer of water which reached about $94.76-97.38 \%$ followed by residential water consumption (1.90-3.05\%), institutional water consumption $(0.71-1.75 \%)$, and touristic water consumption $(0.02-0.43 \%)$, respectively. The future demand forecasting results revealed that the present situation may continue to rise in the next 50 years which will increase the water demand with a water deficit ranging between 15 and $114 \mathrm{MCM} /$ year. To fill the gap between the present water consumption and future residential, institutional, commercial, and touristic water demand, additional municipal facilities, and improvement and management of water supply/demand are needed. To cope with the predicted future water demand, it is recommended to improve the on-farm irrigation, reduce the demand for irrigation
\end{abstract}

\footnotetext{
A. A. Ahmed ( $\square)$

Geology Department, Faculty of Science, Sohag University,

Sohag, Egypt

e-mail: ayman@sohag.edu.eg

G. E. Fogg

Land, Air and Water Resources Department,

University of California, Davis, USA

M. A. Gameh

Soil and Water Science Department, Faculty of Agriculture,

Assiut University, Assiut, Egypt
}

water, rationalize the irrigation water use, and enhance the integrated role of water users in integrated water resources management.

Keywords Water consumption - Water demand forecasting $\cdot$ Luxor $\cdot$ Egypt

\section{Introduction}

Water resources in Egypt are becoming scarce. Surface-water resources originating from the Nile are now fully exploited, while groundwater sources are being brought into full production (Nassar and El-Korashey 2003; Aly 2007; Abdin and Gaafar 2009; Abdin et al. 2011). According to the 1959 agreement with Sudan, Egypt is entitled to 55.5 BCM of the water resource available with $18.5 \mathrm{BCM}$ allocated to Sudan and an amount of $\sim 10 \mathrm{BCM}$ allocated for water losses from the impounded area of the dam (Salman 2010). The Aswan High Dam (AHD) was constructed $\sim 6 \mathrm{~km}$ south of Aswan and commenced operation in 1968. The AHD is the major flow-regulating structure on the River Nile. Downstream from the AHD, the Nile water is diverted from the main channel into an intensive network of irrigation canals to provide water for agricultural use (Abu-Zeid 1991; EEAA 2005).

The demand for clean drinking water supply is one of the most important priorities of the Egyptian government in the recent years. Since construction of the High Dam, growing population, economic growth and agricultural expansion lead to extensive water consumption and increasing water demand. Moreover, climate change and degradation of groundwater quality imposed more challenges on future water demand (El Tahlawi et al. 2008; Ahmed 2009, 2013; El-Nahry and Doluschitz 2010; Ahmed and Ali 2011; Elwaseif et al. 2012; McCarl et al. 2013). 
Fig. 1 Location map of Luxor area

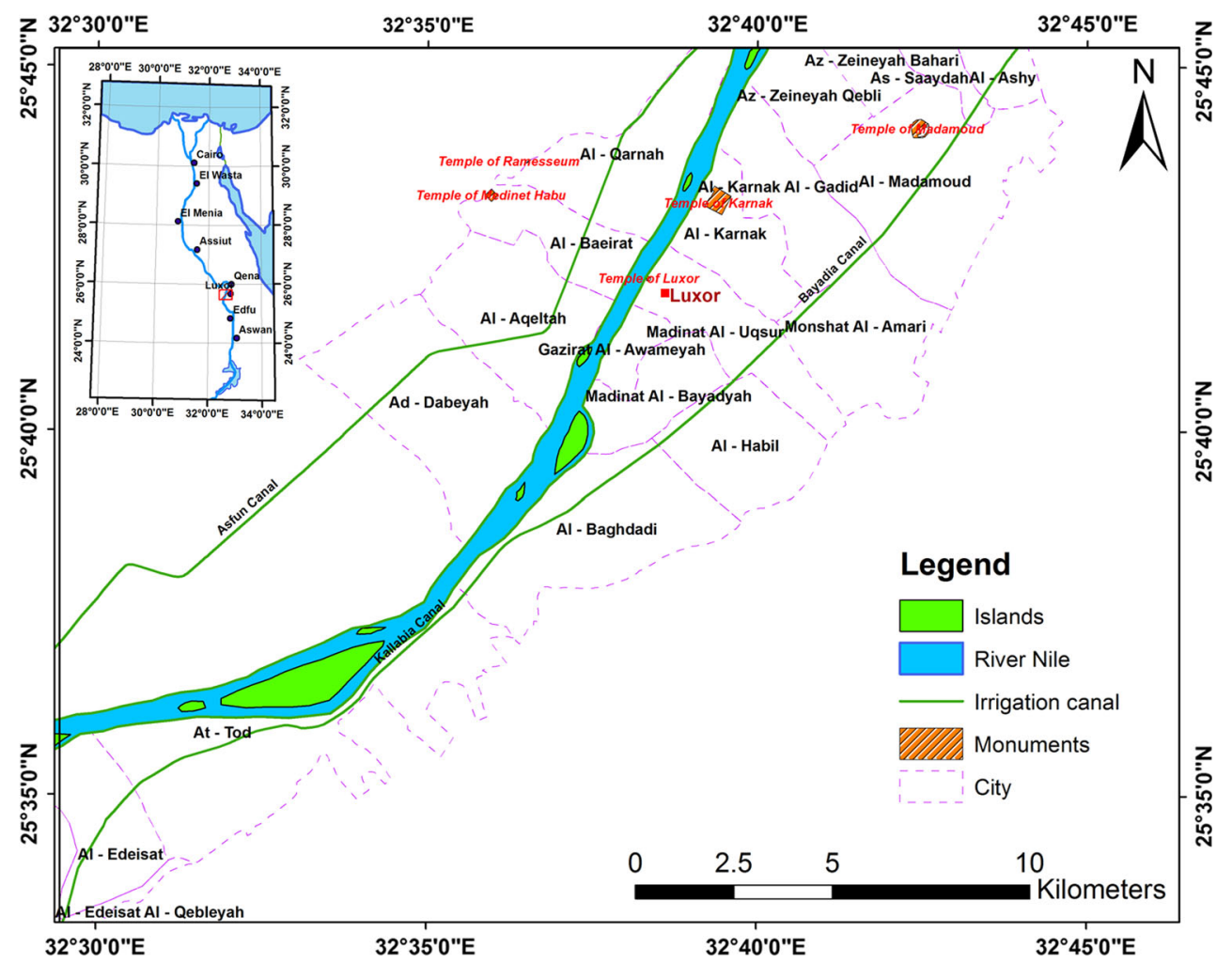

Water in Luxor is used for agricultural, residential, institutional, commercial, and touristic purposes. Management of water demand and filling the gap between present and future water demand is a complex process which requires better identification of water users, water consumption and water demand. Luxor in Upper Egypt is of special concern due to its importance as a famous touristic site that currently attracts more than 4 million tourists per year from all over the world as well as the great changes in population, economy, and agriculture since the construction of the High Dam. Consequently, the objective of this work is to estimate the past, present and future water demand at Luxor to help planners and decision makers on management water resources and water demand.

\section{Study area}

Luxor is in Upper Egypt and the capital of Luxor Governorate with an area of $\sim 416 \mathrm{~km}^{2}$ (Fig. 1). Luxor was a city belonging to Qena Governorate but was separated administratively and became a new governorate called "Luxor Governorate" in Dec 2009. The city of Luxor was assigned as capital of the Luxor governorate. Agricultural lands represent about $73.8 \%$ of the total area, whereas urban areas cover about $19.4 \%$, and about $6.8 \%$ is barren lands on both sides of the Nile Valley. Luxor area constitutes a primary center of ancient Egyptian culture where the culture of ancient Egypt has been imprinted along the Nile
Valley by means of the famous pharaonic monuments remaining in a good form of preservation. The area of study includes many archaeological sites on both sides of the River Nile such as temples of Luxor, Karnak, Medinet Habu, Ramsium, the Memnon Clossi, in addition to the famous tombs such as the Valley of Kings and Valley of Queens (Baines and Malek 2000).

\section{Climate}

Luxor area is characterized by arid and desert conditions. The maximum air temperature varies between $22.9^{\circ} \mathrm{C}$ in Jan and $40.9{ }^{\circ} \mathrm{C}$ in Jul whereas the average minimum temperature varies between $5.7{ }^{\circ} \mathrm{C}$ in Jan and $23.9{ }^{\circ} \mathrm{C}$ in Jul. The monthly average of relative humidity in the study area ranges between $25.0 \%$ in May and $55.0 \%$ in Dec. The monthly average of wind speed varies in time and location with monthly averages ranging between $5.9 \mathrm{~km} / \mathrm{h}$ in Oct and $9.3 \mathrm{~km} / \mathrm{h}$ in Apr. Rains are rare and occur randomly throughout the year. The monthly average of precipitation ranges between 0.0 and $0.3 \mathrm{~mm}$ (Ibrahim 1996; Ahmed 2003; EEAA 2005; Tyson 2010).

\section{Agriculture and irrigation}

The Nile Valley of Egypt is one of the oldest agricultural areas in the world, having been under continuous cultivation for at least 5,000 years (Crush 1995; Nasr 1997; 
Fig. 2 Geologic map of Luxor area [compiled from Klitzsch and Wycisk (1987) shown by Kamel (2004)]

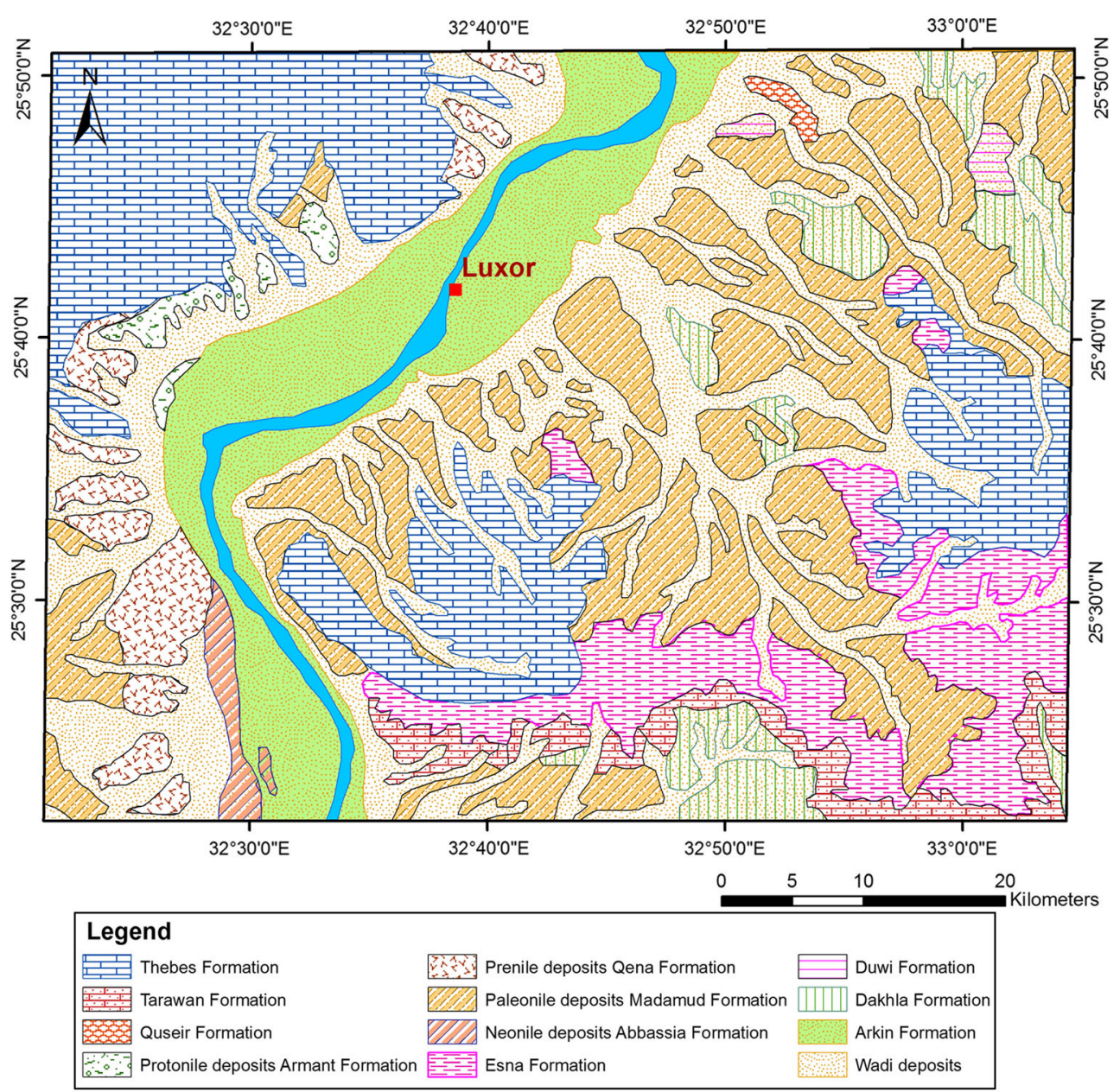

Sallam 2003). Before construction of the High Dam, only one crop per year was produced by flood irrigation. After construction of the High Dam, the production was changed completely to perennial irrigation whereby water is available at any time throughout the year, thus producing two or more crops annually (Abu-Zeid 1997; Abu-Zeid and El-Shibini 1997; Hegazi and El Bagouri 2002).

The entire valley is mainly used for agricultural activities except for the areas of settlements. The edges of the valley on the east and west flanks are marked by new cultivated fringes. Crops are cultivated in a 2- or 3-year crop rotation divided into winter, summer, and Nili (autumn) crops. Winter cultivation season starts in October-November and summer season starts in May-June (Rosenzweig and Hillel 1994; Abou Hussein and Sawan 2010).

There are two main canals in the study area that take water directly from the Nile upstream of the Esna barrage; these are the Asfun and Al-Kallabiyya canals (Fig. 1). The old Esna barrage was constructed in 1908 on the Nile $170 \mathrm{~km}$ downstream of Aswan, and $61 \mathrm{~km}$ upstream of Luxor, to guarantee basin irrigation in the southern reaches of Upper Egypt. In 1994 the new Esna barrage was constructed $1.2 \mathrm{~km}$ downstream of the existing structure. The total cultivated area observed at Luxor is about 79,000 feddan.

\section{Geologic setting}

The geology of Luxor area (Fig. 2) is represented by Upper Cretaceous, Paleocene-Eocene, Pliocene, and PleistoceneHolocene as follows (Said 1981; Wendorf and Schild 2002; Kamel 2004):

The Pliocene unit comprises the sediments of the Paleonile river system. It is represented in Luxor area by two formations, namely: Pliocene fault breccia or intraformational conglomerate and Madamud Formation, which is made up of interbedded red brown clays with thin finegrained sand and silt laminae.

The Pleistocene unit comprises the Protonile sediments of Early Pleistocene, the Prenile sediments of the Middle Pleistocene, and the Neonile sediments of Late Pleistocene age. The Protonile sediments are represented by Arment Formation which is made up of pebbly and bouldery gravels, while the Prenile sediments are represented by Qena Formation, which is composed of cross-bedded 
Fig. 3 Simplified hydrostratigraphic section representing Luxor area [compiled from RIGW (1997) and Klitzsch and Wycisk (1987) shown by Kamel (2004)]

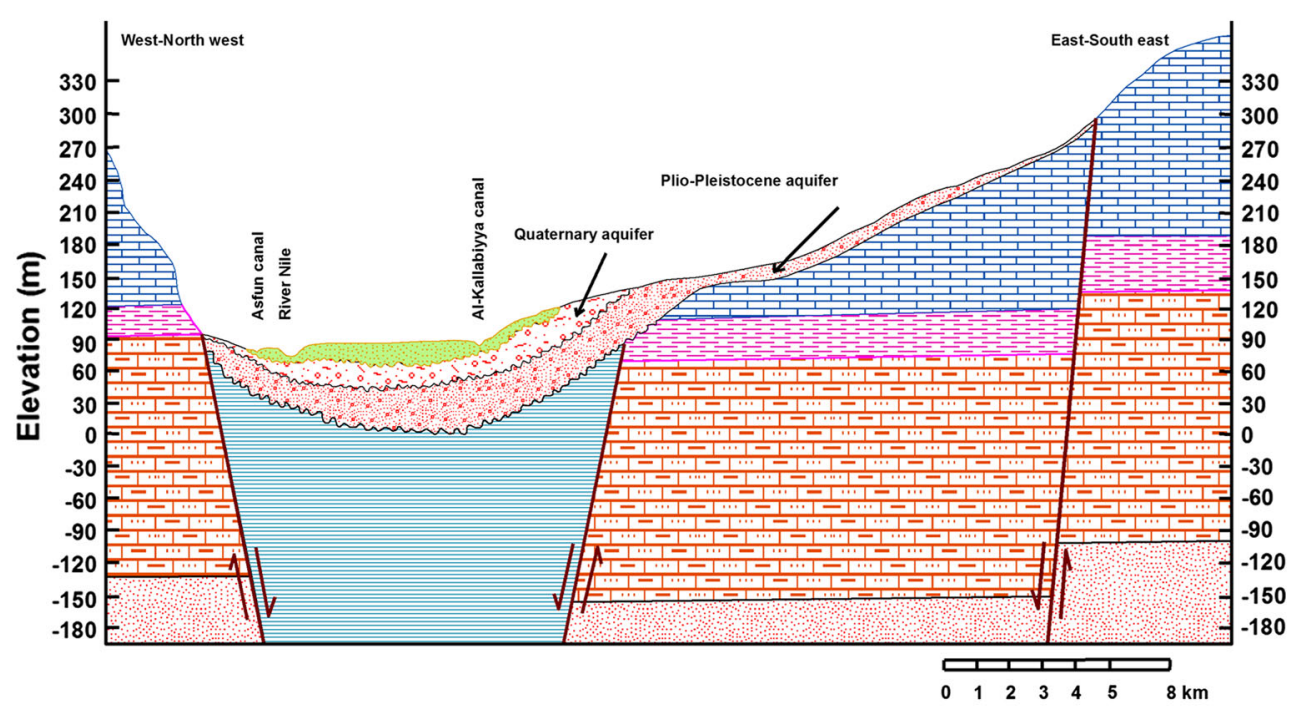

Legend
Semi-confined silty clay (Arkin Formation)
Graded sand and gravel intercalated with clay lenses
(Qena and Abbassia Formations)
Sand and clay intercalations with gravel
(Armant Formation)

fluvial sands with minor gravel and clay beds and the Abbassia Formation, which is made up of massive loosely consolidated gravel of polygenetic origin.

The Holocene unit is represented by the Neonile sediments (Arkin Formation). It is made up of silt, micaceous sand, and clays. The recent alluvial cover comprises unconsolidated sediments represented by Nile flood plain unit and attains a total thickness of $18.5 \mathrm{~m}$, made up of two sequential layers, silty clay and clay layers.

\section{Hydrogeology}

The surface water hydrology of the area is mainly given by the River Nile and irrigation canals. Two principal groundwater aquifers are to be distinguished at Luxor area (Fig. 3):

\section{The Quaternary aquifer}

The aquifer occupies the central strip on the Nile Valley forming the old cultivated lands on both sides of the Nile and forms the most important water-bearing formation in Luxor area. This aquifer can be categorized into two hydrogeological units: the Upper Holocene aquitard and the Lower Pleistocene aquifer.

The Holocene aquitard including the phreatic groundwater is equivalent to the Neonile sediments (Arkin Formation) (Said 1981). This unit is made up of two sequential layers, a silty clay layer (18.5 m thick) which changes laterally into clay and fine sand, and a clay silt layer (13.5 $\mathrm{m}$ thick) at the base. The layer has greater thickness near the river channel and vanishes near the valley fringes. This unit has low horizontal and vertical permeability and receives the surface water seepage forming subsoil water and acts as an aquitard to the underlying aquifer (Barber and Carr 1981; Ahmed 2003, 2009; Kamel 2004).

The Pleistocene aquifer is equivalent to the Protonile sediments of Early Pleistocene (Arment Formation) and the Prenile sediments of the Middle Pleistocene (Qena and Abbassia formations). It is mainly formed of unconsolidated pebbly and bouldery gravel changed laterally into medium to coarse sands and gravel. The Pleistocene sediments about $64.5 \mathrm{~m}$ thickness in Luxor area (Kamel 2004) are underlain by more than $100 \mathrm{~m}$ of brown clays of the Pliocene unit (Madamud Formation).

The Pleistocene aquifer has high horizontal and vertical conductivity (Farrag 1982; Awad et al. 1997). The aquifer is highly productive of good water quality. It is recharged mainly from irrigation water and seepage from irrigation canals through the Holocene aquitard (Abu-Zeid 1995; Shamrukh et al. 2001; Shamrukh and Abdel-Wahab 2008; Brikowski and Faid 2006; Ahmed 2003; Kamel 2004). Discharge of this aquifer is through groundwater pumping for irrigation and drinking purposes and natural discharge towards the River Nile (RIGW/IWACO 1997; Shahin 1991; Awad et al. 1997; Ahmed 2003). 


\section{The Pliocene-Pleistocene aquifer}

This aquifer represents the secondary aquifer in the study area and is exposed at the outer fringes of the Nile aquifer system adjacent to the floodplain. It is composed of clay, sand, and gravel (Awad et al. 1997; Kamel 2004; Ismail et al. 2005). The aquifer has more thickness near the Quaternary aquifer and decreases towards the Eocene limestone boundary on both sides of the Nile valley. At the valley fringes, the groundwater in this aquifer is under phreatic conditions. This aquifer is of low productivity. The recharge of this aquifer is mainly from excess irrigation from the reclaimed and desert lands and from deeper aquifer systems (RIGW 1997). Discharge of this aquifer is through the groundwater pumping or to adjacent groundwater aquifers (Awad et al. 1997).

\section{Methodology}

\section{Definition of water users}

The water users at Luxor area could be classified into agricultural, institutional, residential, touristic, and commercial. Agricultural water consumption includes water used for irrigation purposes. Institutional water consumption includes public facilities dedicated to public service including schools, governmental buildings and hospitals. Residential water consumption includes water use for drinking and domestic purposes. Touristic water consumption includes the water used by tourists. Commercial water consumption includes private facilities providing or distributing a product or service such as hotels, restaurants, or office buildings. Industrial water consumption includes facilities that mostly manufacture or process materials. Commercial and institutional users of water could be grouped together for analytical purposes because the distinction between commercial and institutional units is somewhat arbitrary such as the distinction between private and public schools.

\section{Estimation of water consumption}

The estimation of water consumption in million cubic meters (MCM) for the different water users at Luxor could be summarized as follows:

\section{Agricultural water consumption}

CROPWAT 8.0, a computer program for irrigation planning and management (FAO 1992, 1998), is used for the calculation of crop water requirements based on soil, climate and crop data (Smith 1992, 1993). The model calculates reference evapotranspiration $\left(\mathrm{ET}_{0}\right)$ based on the FAO Penman-Monteith method (Allen et al. 1998) as follows (Eq. 1):

$$
\begin{aligned}
\mathrm{ET}_{0}= & \left\{0.408 \Delta\left(R_{\mathrm{n}}-G\right)+\gamma(900 / T+273) U_{2}\left(e_{\mathrm{s}}-e_{\mathrm{a}}\right)\right\} / \\
& \Delta+\gamma\left(1+0.34 U_{2}\right)
\end{aligned}
$$

where $\mathrm{ET}_{0}$, reference evapotranspiration $\left(\mathrm{mmday}^{-1}\right) ; R_{\mathrm{n}}$, net radiation at the crop surface $\left(\mathrm{MJm}^{-2} \mathrm{day}^{-1}\right) ; G$, soil heat flux density $\left(\mathrm{MJm}^{-2} \mathrm{day}^{-1}\right) ; T$, mean daily air temperature at $2 \mathrm{~m}$ height $\left(C_{0}\right) ; U_{2}$, wind speed at $2 \mathrm{~m}$ height $\left(\mathrm{ms}^{-1}\right) ; e_{\mathrm{s}}$, saturation vapor pressure $(\mathrm{kPa}) ; e_{\mathrm{a}}$, actual vapor pressure $(\mathrm{kPa}) ; e_{\mathrm{s}}-e_{\mathrm{a}}$, saturation vapor pressure deficit $(\mathrm{kPa}) ; \Delta$, slope vapor pressure curve $\left(\mathrm{kPa}^{\circ} \mathrm{C}^{-1}\right) ; \gamma$, psychrometric constant $\left(\mathrm{kPa}^{\circ} \mathrm{C}^{-1}\right)$.

$\mathrm{ET}_{\mathrm{C}}$ is termed as the crop water requirement which is defined as the depth of water needed to meet the water loss through evapotranspiration of a disease-free crop, growing in fields under non-restricting soil conditions including soil water and fertility and achieving full production under the given growing environment (Doorenbos and Pruitt 1977; Doorenbos and Kassam 1979; Zhiming et al. 2007). The CROPWAT program first computes Penman-Monteith reference evapotranspiration $\left(\mathrm{ET}_{0}\right)$ and then adjusts this generalized variable for each crop using seasonal growth curves $\left(K_{\mathrm{C}}\right.$ parameters) as follows (Eq. 2):

$\mathrm{ET}_{\mathrm{C}}=K_{\mathrm{C}} \times \mathrm{ET}_{0}$

where $K_{\mathrm{C}}$ is the crop coefficient which is defined as ratio of the actual crop evapotranspiration $\left(\mathrm{ET}_{\mathrm{C}}\right)$ to reference crop evapotranspiration $\left(\mathrm{ET}_{0}\right)$ (Doorenbos and Pruitt 1975, 1977; Burman et al. 1980a, b; Allen et al. 1998, 2005; Allen 2003). Crops grown at Luxor area were used for calculation of crop water requirements according to the crop pattern listed in Table 3.

\section{Residential water consumption}

Residential water consumption at Luxor was calculated based on the population in Luxor city and the average of daily water use. The average water consumption in Luxor is considered as $160 \mathrm{~L}$ /person/day (EEAA 2005; MHUUD 2007) and assuming a constant per capita consumption rate for the study period.

\section{Institutional and commercial water consumption}

Municipal water use is gathered for recent years for the purpose of estimating the rate of yearly water consumption for the different institutional and commercial sectors at the study area. The total daily average of water consumption is estimated at $17.88 \mathrm{~m}^{3} /$ day/establishment. The total institutional and commercial water consumption is calculated as follows (Eq. 3): 
$W_{\mathrm{IC}}=\sum_{s=1}^{n}\left(W_{s} \times S_{s}\right)$

where $W_{\mathrm{IC}}$, institutional and commercial total water consumption for $n$ sectors; $W_{\mathrm{s}}$, water consumption rate for sector $S ; S_{\mathrm{s}}$, Size of sector $S$.

\section{Touristic water consumption}

Most projections assumed that tourists consume more water than city residents do. The touristic water consumption was calculated using an average of $400 \mathrm{~L} /$ person/ day (Abraham and Bakr 2000; Lamei 2009; Charalambous et al. 2012).

\section{Water demand}

The water demand at Luxor area is calculated in MCM as the total water consumption as follows (Eq. 4):

$W_{\mathrm{D}}=\sum_{U=1}^{n}\left(W_{U}\right)$

where $W_{\mathrm{D}}$, water demand; $W_{U}$, water consumption for user $U$.

Forecasting the future water demand

\section{Regression analysis}

The linear regression analysis is used for analyzing the future water demand at Luxor. Regression analysis is a statistical technique that attempts to explore and model the relationship between two or more variables. A linear regression model attempts to explain the relationship between two or more variables using a straight line (Walpole et al. 2007; Dowdy et al. 2004). The statistical relation between the years of observation (the independent variable termed as $X$ ) and water consumption (the dependent variable termed as $Y$ ) may be expressed as follows (Eq. 5):

$Y=\beta_{0}+\beta_{1} x+\varepsilon$

In this model, the mean value of $Y$, abbreviated as $E(Y)$, is assumed to follow the linear relation (Eq. 6):

$E(Y)=\beta_{0}+\beta_{1} x$

The actual values of $Y$ are assumed to be the sum of the mean value, $E(Y)$ and a random error term $(\varepsilon)$ as follows (Eq. 7):

$$
\begin{aligned}
Y & =E(Y)+\varepsilon \\
& =\beta_{0}+\beta_{1} x+\varepsilon
\end{aligned}
$$

The slope, $\beta_{1}$, and the intercept, $\beta_{0}$, of the line $E(Y)=$ $\beta_{0}+\beta_{1} x$ are called regression coefficients. The random error term, $\in$, is assumed to follow the normal distribution with a mean of 0 and variance of $\sigma^{2}$. Since $Y$ is the sum of this random term and the mean value, $E(Y)$, which is a constant, the variance of $Y$ at any given value of $X$ is also $\sigma^{2}$. Therefore, at any given value of $x$, say $x_{i}$, the dependent variable $Y$ follows a normal distribution with a mean of $=\beta_{0}+\beta_{1} x_{i}$ and a standard deviation of $\sigma^{2}$ (Walpole et al. 2007; Dowdy et al. 2004).

The regression line can be estimated by estimating the coefficients $\beta_{1}$ and $\beta_{0}$ for an observed data set. The estimates, $\widehat{\beta}_{1}$ and $\widehat{\beta}_{0}$, could be calculated efficiently using the least squares method (Tucson 2005; Johnson and Bhattacharyya 2010). The least-squares line is determined such that the sum of the squares of the deviations of the data points from the line is a minimum. (Johnson and Kuby 2012).

In the present study, the statistical software package SPSS 17.0 (2007) is used in the present study for regression analysis and estimating the regression coefficients to be used for building the statistical model for the future forecasting of water demand.

\section{Building the statistical model for future forecasting}

According to the regression analysis, the projected future water demand $(Y)$ is a random variable that is related to the future projected years of observation $(X)$ by the following relation (Eq. 8):

$Y_{i}=\beta_{0}+\beta_{1} x_{i}+e_{i} \quad i=1, \ldots \ldots \ldots \ldots, n$

where, $Y_{i}$ denotes the projected future water demand corresponding to the $i^{\text {th }}$ projected year of observation $(X)$ set at the value $X_{i}$. The terms $e_{1}, \ldots \ldots, n$ are the unknown error components that are superimposed on the true linear relation. These are unobservable random variables, which we assume are independently and normally distributed with mean zero and an unknown standard deviation $\sigma$. The parameters $\beta_{0}$ and $\beta_{1}$, which together locate the straight line, are unknown.

\section{Projected future scenarios}

Four scenarios could be expected for projected water demand at Luxor area up to 2050 as follows: scenario 1: linear increase in agricultural, residential, institutional and touristic water consumption. scenario 2: stabilization in agricultural water consumption and linear increase in residential, institutional and touristic water consumption. scenario 3: stabilization in agricultural and institutional water consumption and linear increase in residential and touristic water consumption. scenario 4: stabilization in agricultural, institutional and touristic water consumption and linear increase in residential water consumption. 
Table 1 Luxor climatic data used for calculating the crop water (Ibrahim 1996; Ahmed 2003; EEAA 2005; Tyson 2010)

\begin{tabular}{|c|c|c|c|c|c|c|c|c|c|c|c|c|}
\hline Month & Jan & Feb & Mar & April & May & Jun & Jul & Aug & Sep & Oct & Nov & Dec \\
\hline $\operatorname{Min}\left({ }^{\circ} \mathrm{C}\right)$ & 5.7 & 7.1 & 11.0 & 16.0 & 20.4 & 22.8 & 23.9 & 23.5 & 21.6 & 17.8 & 12.0 & 7.5 \\
\hline $\operatorname{Max}\left({ }^{\circ} \mathrm{C}\right)$ & 22.9 & 25.2 & 29.3 & 35.0 & 38.9 & 41.1 & 40.9 & 40.6 & 38.8 & 35.3 & 29.4 & 24.4 \\
\hline Relative humidity (\%) & 54 & 45 & 36 & 29 & 25 & 25 & 28 & 30 & 34 & 40 & 49 & 55 \\
\hline Wind speed $(\mathrm{km} / \mathrm{h})$ & 7 & 8 & 8.7 & 9.3 & 8.3 & 8.1 & 7.8 & 7.4 & 6.5 & 5.9 & 6.1 & 6.3 \\
\hline Hours of daylight & $10: 44$ & $11: 17$ & $12: 00$ & $12: 45$ & $13: 23$ & $13: 43$ & $13: 35$ & $13: 03$ & $12: 20$ & $11: 35$ & $10: 56$ & $10: 35$ \\
\hline Hours of sunshine & 9:08 & $9: 45$ & 9:49 & $10: 25$ & 11:06 & $12: 15$ & $12: 07$ & $11: 49$ & $10: 30$ & 10:12 & $9: 35$ & $8: 45$ \\
\hline Area of blue sky (\%) & 86 & 88 & 86 & 89 & 90 & 97 & 96 & 97 & 97 & 93 & 91 & 86 \\
\hline Rainfall (mm) & 0.0 & 1.0 & 4.0 & 0.0 & 0.0 & 0.0 & 0.0 & 0.0 & 0.0 & 0.0 & 0.0 & 0.0 \\
\hline
\end{tabular}

Data acquisition

\section{Climatic data}

The respective climatic data used for calculating the crop water requirements are collected for Luxor meteorological station according to Ibrahim (1996), Ahmed (2003), EEAA (2005) and Tyson (2010). The climatic data collected include temperature, humidity, wind speed, sunshine hours and rainfall (Table 1).

\section{Crop pattern}

There are three distinct planting seasons in Egypt (FAO 1995; El-Nahrawy 2011): winter (November to May), summer (April/May to October) and Nili seasons (July/ August to October). The Nili season corresponds to late July to early November and takes its name from agricultural practices dating back before the control structures on the Nile when the River still used to flood every year.

Before construction of the AHD, the winter season used to be the primary production season following the flood. Perennial irrigation following the dam construction resulted in maximum water consumption for the summer season (CEDARE 2011). Furthermore, crops for one season may harvested before those of the previous season have been harvested. Thus providing yields for 2-3 crops annually. The crop pattern for year 2011 was assumed as a reference year to calculate the total agricultural water consumption at Luxor (Table 2).

\section{Cropped area}

Three sets of Landsat imagery were used for analysis of agricultural expansion and estimation of cropped area at Luxor; Landsat MSS (Multi Spectral Scanner), Landsat Thematic Mapper (TM), and Enhanced Thematic Mapper (ETM+) images (Path 188/Row 42) for the period 1987-2011 (Fig. 4).
Table 2 Crop pattern and cropped area for 2011 at Luxor (MALR 2012)

\begin{tabular}{llr}
\hline Season & Crop & $\begin{array}{r}\text { Cropped area } \\
\text { (feddan) }\end{array}$ \\
\hline Permanent & Sugar cane & $65,296.68$ \\
& Fruit trees, orchards, date palms & $8,757.25$ \\
Winter & Alfalfa & $4,412.21$ \\
& Clover & $4,547.21$ \\
& Wheat & $44,203.75$ \\
Tomato & $8,958.57$ \\
Dummer and Nili & Dry beans & 400.21 \\
& Garlic & 216.42 \\
& Vegetables, water melon & $3,373.51$ \\
& Barley & 270.17 \\
& Onion & 648.42 \\
& Fename & 3.00 \\
& Vegetables & $18,446.20$ \\
& Peanuts & $2,418.50$ \\
& Roselle & $2,650.33$ \\
& Sorghum & 144.33 \\
& Soybean & 470.29 \\
& Tomato & 578.29 \\
& & 100.00 \\
& & 839.96 \\
\hline
\end{tabular}

${ }^{\mathrm{a}}$ Feddan 2,400 $\mathrm{m}^{2}$, ${ }^{\mathrm{b}}$ may be grown as Nili crop

\section{Population data}

The population data of Luxor (Table 3) were collected from the preliminary results of General Census of population, housing and establishments (CAPMAS 2012) and World Gazetteer (2010).

\section{Touristic data}

The number of tourists visiting Luxor was around $30 \%$ of tourists visiting Egypt every year (Table 4). The visitors of Luxor were staying an average of three nights (MI 2008). 
Fig. 4 Landsat image (Landsat 7 ETM+) of year 2011, RGB 532, showing agricultural areas with green color

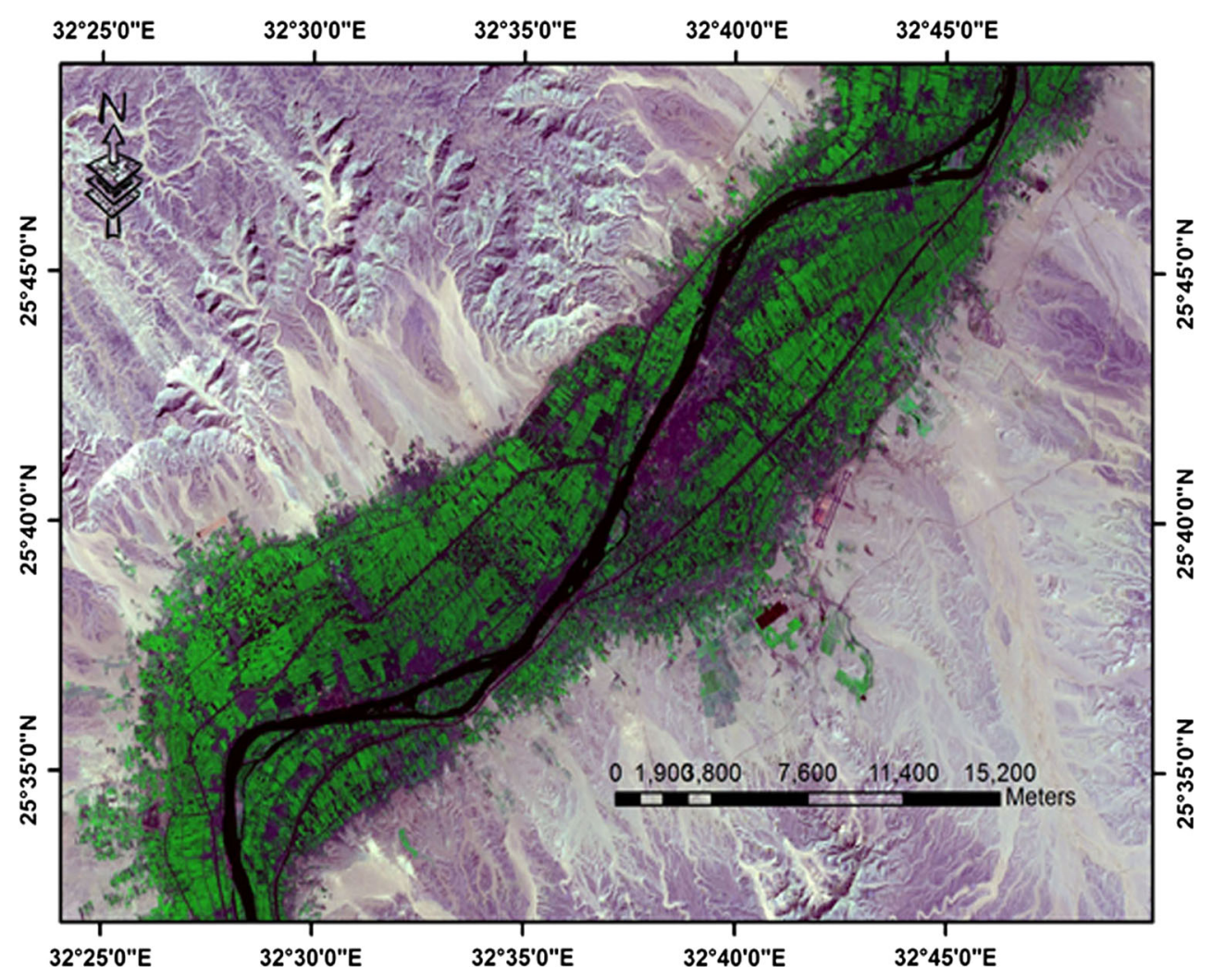

Table 3 Total population of Luxor (CAPMAS 2012; World Gazetteer 2010)

\begin{tabular}{lllllllll}
\hline Year & 1969 & 1970 & 1973 & 1974 & 1975 & 1976 & 1977 \\
Population & 190,000 & 194,100 & 206,700 & 213,000 & 218,302 & 223,904 & 209,187 & 215,324 \\
Year & 1979 & 1980 & 1981 & 1983 & 1984 & 1986 & 1987 \\
Population & 229,804 & 235,979 & 242,568 & 255,617 & 262,753 & 269,717 & 279,698 \\
Year & 1989 & 1990 & 1991 & 1992 & 1993 & 1994 & 1996 \\
Population & 296,559 & 305,263 & 312,661 & 320,856 & 328,308 & 336,301 & 357,562 \\
Year & 1999 & 2000 & 2002 & 2006 & 2010 & & 372,960 \\
Population & 365,782 & 388,368 & 380,452 & 457,286 & $496,436^{\mathrm{a}}$ & & & \\
\hline
\end{tabular}

${ }^{a}$ Estimated data (World Gazetteer 2010)

Table 4 The total number of tourist arrivals in Egypt (MI 2008; Abraham and Bakr 2000; Rady 2002; Lanquar 2011; Indexmundi 2013; UNWTO 2013; CAPMAS 2013)

\begin{tabular}{lllllllll}
\hline Year & 1981 & 1982 & 1983 & 1984 & 1985 & 1986 & 1987 \\
No. tourists & 1376,000 & 1423,300 & 1497,900 & 1560,500 & 1518,400 & 1311,300 & 1795000 & 1969,500 \\
Year & 1989 & 1990 & 1991 & 1992 & 1993 & 1994 & 1995 \\
No. tourists & 2503,400 & 2600,100 & 2214,300 & 3206,900 & 2507,800 & 2582,000 & 3133,500 & 3895,900 \\
Year & 1997 & 1998 & 1999 & 2000 & 2001 & 2002 & 2003 \\
No. tourists & 3961,400 & 3453,900 & 4796,500 & 5506,600 & 4357,000 & 4906,000 & 5746,000 & 7795,000 \\
Year & 2005 & 2006 & 2007 & 2008 & 2009 & 2010 & \\
No. tourists & 8244,000 & 8646,000 & 10610,000 & 12296,000 & 11914,000 & 14051,000 & \\
\hline
\end{tabular}


Table 5 Number of water user sectors at Luxor (CAPMAS 2006a, b, c, 2007a, b, c, d; Abraham et al. 2000)

\begin{tabular}{|c|c|c|c|c|c|c|c|c|}
\hline \multirow[t]{2}{*}{ Establishment } & \multicolumn{8}{|l|}{ Year } \\
\hline & 1970 & 1985 & 1986 & 1989 & 1996 & 2000 & 2006 & 2012 \\
\hline School & 30.0 & 32.0 & 34.0 & $419.5^{\mathrm{a}}$ & $612.3^{\mathrm{a}}$ & $708.6^{\mathrm{a}}$ & $756.8^{\mathrm{a}}$ & 805.0 \\
\hline Hospital & 6.0 & $9.0^{\mathrm{a}}$ & $10.5^{\mathrm{a}}$ & $11.3^{\mathrm{a}}$ & $11.6^{\mathrm{a}}$ & $11.8^{\mathrm{a}}$ & 12.0 & $14.0^{\mathrm{a}}$ \\
\hline Medical unit & 4.0 & $21.5^{\mathrm{a}}$ & $30.3^{\mathrm{a}}$ & $34.6^{\mathrm{a}}$ & $36.8^{\mathrm{a}}$ & 39.0 & 44.0 & $53.8^{\mathrm{a}}$ \\
\hline Mosque & 18.0 & $632.5^{\mathrm{a}}$ & $939.8^{\mathrm{a}}$ & $1,093.4^{\mathrm{a}}$ & $1,170.2^{\mathrm{a}}$ & $1,208.6^{\mathrm{a}}$ & $1,227.8$ & $1,247.0$ \\
\hline Total & 58.0 & 695.0 & $1,014.5$ & $1,558.8$ & $1,830.9$ & $1,968.0$ & $2,040.6$ & $2,119.8$ \\
\hline
\end{tabular}

${ }^{\text {a }}$ Estimated

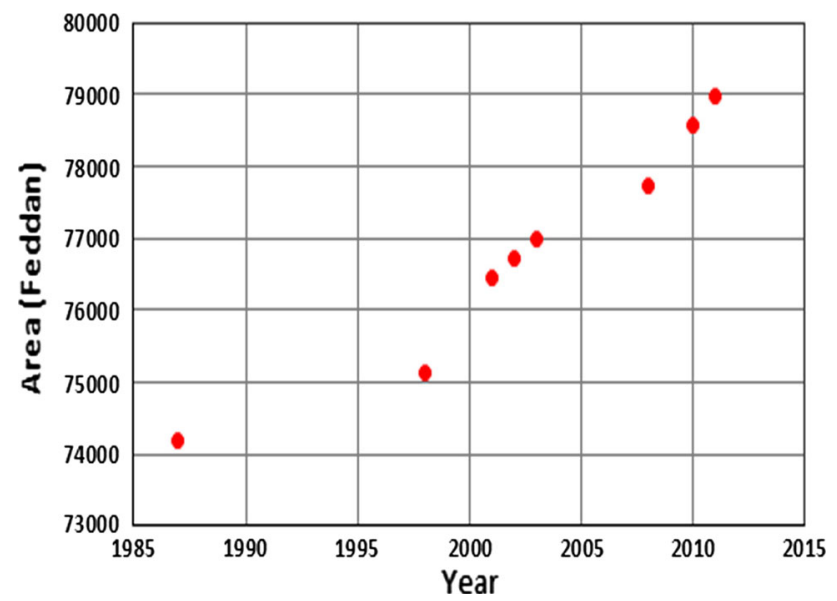

Fig. 5 Agriculture expansion at Luxor area (in feddan) based on Landsat imagery analysis

\section{Institutional and commercial data}

The institutional and commercial data are represented by the establishments consuming water (Table 5).

\section{Results}

Analysis of Landsat imagery revealed that agricultural lands were increased by about 4,790 feddan from 1987 to 2011 (Fig. 5). Climate plays an important role in agricultural water consumption. The calculated crop water requirements indicated that March to August are the most water consuming period during the year (Table 6). The yearly agricultural water consumption ranged between 801.85 MCM (year 1987) and 853.63 MCM (year 2011) based on an irrigation water requirement of $10,806.81 \mathrm{~m}^{3} /$ year/feddan according to CROPWAT results (Fig. 6).

For the time period 1983-2012, the highest water consumption is for agriculture which attains about 94.76-97.38\% followed by residential water consumption $(1.90-3.05 \%)$, institutional water consumption $(0.71-1.75 \%)$ and touristic water consumption $(0.02-0.43 \%)$ respectively (Fig. 6). Agriculture water consumption ranged between 801.86 MCM (year 1987) and 849.14 MCM (year 2011), residential water consumption ranged between 11.10 MCM (year 1969) and 28.99 MCM (year 2010), institutional and commercial water consumption ranged between $0.38 \mathrm{MCM}$ (year 1970) and 13.83 MCM (year 2012), whereas touristic water consumption ranged between 0.47 MCM (year 1986) and 5.06 MCM (year 2010). The total water consumption at Luxor area ranged between $808.93 \mathrm{MCM}$ (year 1983) and 898.42 MCM (year 2012).

The current estimates of water consumption for year 2012 is about $47.88 \mathrm{MCM}$ compared to the exact water consumption of $48.09 \mathrm{MCM}$ identified by the Holding Company for Water and Wastewater with a difference of 0.21 MCM $(0.44 \%)$ which support the results and analysis.

The forecast analysis of water demand indicated that scenario 1 is the highest water demand scenario where water consumption is assumed to be in a linear increase for all water users up to year 2050 . The future projected water demand shows a regular increase in water demand. The difference in water demand between scenarios 2, 3 and 4 is not significant. Assuming expansion in agriculture, the future water demand may reach about 1,015.69 MCM by year 2050 representing a water deficit of about 114.18 MCM compared with the present situation. On the other hand, and assuming stabilization in agriculture (scenario 2), the projected future water demand may reach about 934.55 MCM by year 2050 and representing a water deficit of about 33.04 MCM compared to the present situation (Fig. 7; Table 7).

\section{Discussion and conclusion}

Luxor witnessed many developments and changes in the last 50 years represented by population growth, agricultural expansion, economic growth and increased tourism. These changes led to a continuous increase in water consumption. It is expected that this increase will continue over the next 50 years requiring more water demand. 
Table 6 CROPWAT calculations crop water requirements $(\mathrm{mm})$ for the main crop pattern at Luxor

\begin{tabular}{|c|c|c|c|c|c|c|c|c|c|c|c|c|c|}
\hline \multirow[t]{2}{*}{ Crop } & \multicolumn{12}{|l|}{ Month } & \multirow[t]{2}{*}{ Total } \\
\hline & Jan & Feb & Mar & Apr & May & Jun & Jul & Aug & Sep & Oct & Nov & Dec & \\
\hline Sugarcane & 0.0 & 46.2 & 114.1 & 253.7 & 319.3 & 329.4 & 335.5 & 314.7 & 258.9 & 184.6 & 97.6 & 0.0 & $2,254.0$ \\
\hline $\begin{array}{l}\text { Gardens and date } \\
\text { palm }\end{array}$ & 95.7 & 104.0 & 155.4 & 198.2 & 233.0 & 247.9 & 255.8 & 240.0 & 197.5 & 158.7 & 119.7 & 94.6 & $2,100.5$ \\
\hline Alfalfa & 0.0 & 0.0 & 69.1 & 120.4 & 225.1 & 250.3 & 252.2 & 187.4 & 90.6 & 0.0 & 0.0 & 0.0 & $1,195.1$ \\
\hline Clover & 94.4 & 112.8 & 152.9 & 0.0 & 0.0 & 0.0 & 0.0 & 0.0 & 0.0 & 62.3 & 68.3 & 84.0 & 574.7 \\
\hline Wheat & 111.6 & 126.3 & 25.2 & 0.0 & 0.0 & 0.0 & 0.0 & 0.0 & 0.0 & 0.0 & 36.1 & 48.9 & 348.1 \\
\hline Tomato & 20.6 & 0.0 & 0.0 & 0.0 & 0.0 & 0.0 & 0.0 & 0.0 & 120.5 & 136.7 & 140.4 & 102.6 & 520.8 \\
\hline Beans & 37.3 & 0.0 & 0.0 & 0.0 & 0.0 & 0.0 & 0.0 & 0.0 & 0.0 & 70.5 & 122.4 & 111.4 & 341.6 \\
\hline Garlic & 14.8 & 0.0 & 0.0 & 0.0 & 0.0 & 0.0 & 0.0 & 53.2 & 179.9 & 188.6 & 140.2 & 84.2 & 660.9 \\
\hline Vegetables & 87.5 & 0.0 & 0.0 & 0.0 & 0.0 & 0.0 & 0.0 & 0.0 & 140.7 & 135.2 & 126.9 & 101.4 & 591.7 \\
\hline Barley & 114.4 & 131.1 & 95.7 & 0.0 & 0.0 & 0.0 & 0.0 & 0.0 & 0.0 & 0.0 & 49.2 & 102.7 & 493.1 \\
\hline Onion & 113.2 & 102.0 & 31.6 & 0.0 & 0.0 & 0.0 & 0.0 & 0.0 & 0.0 & 32.9 & 107.9 & 108.4 & 496.0 \\
\hline Fenugreek & 86.3 & 9.4 & 0.0 & 0.0 & 0.0 & 0.0 & 0.0 & 0.0 & 0.0 & 32.4 & 85.2 & 111.2 & 324.5 \\
\hline Maize & 0.0 & 0.0 & 0.0 & 0.0 & 90.4 & 269.4 & 291.4 & 32.8 & 0.0 & 0.0 & 0.0 & 0.0 & 684.0 \\
\hline Sesame & 0.0 & 0.0 & 0.0 & 48.2 & 241.5 & 175.0 & 0.0 & 0.0 & 0.0 & 0.0 & 0.0 & 0.0 & 464.7 \\
\hline Vegetables & 0.0 & 0.0 & 0.0 & 157.1 & 247.1 & 274.3 & 271.8 & 63.6 & 0.0 & 0.0 & 0.0 & 0.0 & $1,013.9$ \\
\hline Peanuts & 0.0 & 0.0 & 0.0 & 47.9 & 151.6 & 293.8 & 90.9 & 0.0 & 0.0 & 0.0 & 0.0 & 0.0 & 584.2 \\
\hline Roselle & 0.0 & 0.0 & 0.0 & 94.9 & 269.8 & 301.4 & 298.0 & 194.3 & 54.7 & 0.0 & 0.0 & 0.0 & $1,213.1$ \\
\hline Sorghum & 0.0 & 0.0 & 0.0 & 0.0 & 73.1 & 169.8 & 266.1 & 134.6 & 0.0 & 0.0 & 0.0 & 0.0 & 643.6 \\
\hline Soybean & 0.0 & 0.0 & 0.0 & 0.0 & 0.0 & 0.0 & 0.0 & 0.0 & 134.0 & 292.6 & 132.6 & 559.2 & $1,118.4$ \\
\hline Tomato & 0.0 & 0.0 & 0.0 & 132.3 & 246.6 & 298.9 & 152.9 & 0.0 & 0.0 & 0.0 & 0.0 & 0.0 & 830.7 \\
\hline Total & 775.8 & 631.8 & 644.0 & $1,052.7$ & $2,097.5$ & $2,610.2$ & $2,214.6$ & $1,220.6$ & $1,176.8$ & $1,294.5$ & $1,226.5$ & $1,508.6$ & $16,453.6$ \\
\hline
\end{tabular}

The projected scenarios showed that agriculture is the main controlling factor of water demand. The difference in water demand between scenarios 2, 3 and 4 is not significant. Assuming expansion in agriculture, the future water demand may reach about $1,015.69$ MCM by year 2050 representing a water deficit of about $114.18 \mathrm{MCM}$ compared with the present situation.

On the other hand, and assuming stabilization in agriculture (scenario 2), the projected future water demand may reach about 934.55 MCM by year 2050 representing a water deficit of about $33.04 \mathrm{MCM}$ compared to the present situation.

According to the Comprehensive Plan for the City of Luxor (Abraham et al. 2000), Qena Governorate Environmental Action Plan (EEAA 2005), the continuous population growth, the need for food security, agricultural and economic policies and desert reclamation projects (MALR 2000, 2003), it could be possible to conclude that the present situation may continue to rise in the next 50 years. Consequently, scenarios 1 and 2 are the most probable future situations.

Moreover, Luxor has a local economy based primarily on tourism and the trend for Luxor's economy is to absorb up to 4 million tourists by year 2017. Development of
Luxor city requires establishing of new additional facilities such as schools, day care services, mosques, health units, commercial establishments and tourism lodging (Abraham et al. 2000).

The present hydrogeologic setting of the study area may fit the gap in the probable increase in the agricultural water demand. However, filling the gap between the present water consumption and future residential, institutional and commercial, and touristic water demand (scenarios 2, 3, 4) needs additional municipal facilities, improvement and management of water supply and demand.

The following options could be taken into consideration in dealing with future water demand.

1. Improving on farm irrigation water use by using water saving irrigation methods such as sprinkler and drip irrigation

2. Reducing the demand for irrigation water by reducing the evaporation losses through certain crop patterns and cropping rotations

3. Rationalizing irrigation water use through better scheduling and planning

4. Regular monitoring and improving the efficiency of the water distribution systems and operating structures. 
Fig. 6 a Scatter plot showing agricultural water consumption and the corresponding regression line, b Scatter plot showing residential water consumption and the corresponding regression line, c Scatter plot showing institutional and commercial water consumption and the corresponding regression line, d Scatter plot showing touristic water consumption and the corresponding regression line, e Scatter plot showing the total water consumption, $M C M$ million cubic meters
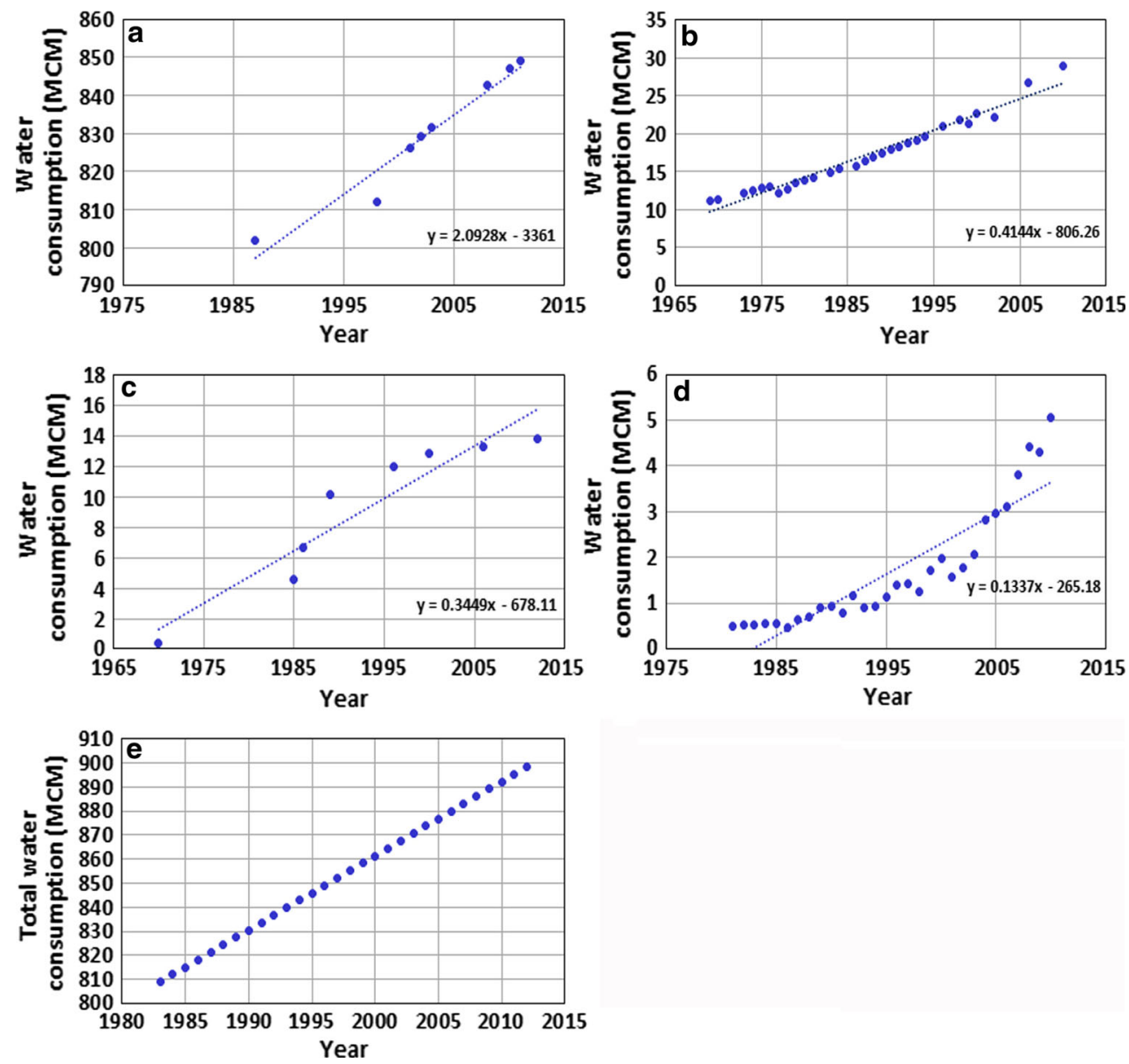

Table 7 Total projected water demand (MCM) for the period 2013-2050

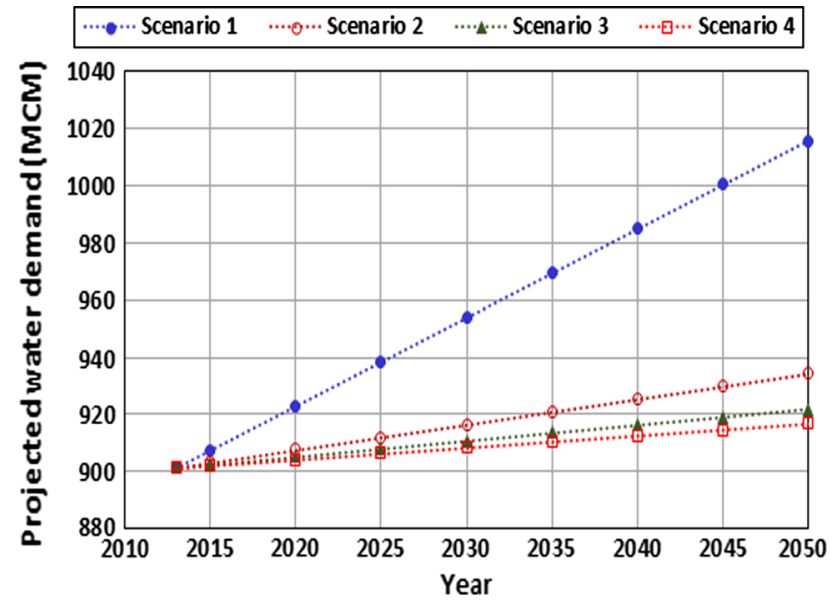

Fig. 7 Projected future water demand from 2012 to 2050. Scenario 1: projected water demand corresponding to linear agricultural, residential, institutional and touristic water consumption. Scenario 2: stabilized agriculture with projected linear residential, institutional and touristic water consumption. Scenario 3: stabilized agriculture and institutional with projected linear residential and touristic water consumption. Scenario 4: proposed stabilization in agriculture, institutional and touristic and projected linear residential water consumption

\begin{tabular}{lcccc}
\hline Year & Scenario 1 & Scenario 2 & Scenario 3 & Scenario 4 \\
\hline 2013 & 901.51 & 901.51 & 901.51 & 901.51 \\
2015 & 907.68 & 903.30 & 902.61 & 902.34 \\
2020 & 923.11 & 907.76 & 905.35 & 904.41 \\
2025 & 938.54 & 912.23 & 908.09 & 906.48 \\
2030 & 953.97 & 916.69 & 910.83 & 908.55 \\
2035 & 969.40 & 921.15 & 913.57 & 910.63 \\
2040 & 984.83 & 925.62 & 916.31 & 912.70 \\
2045 & 1000.26 & 930.08 & 919.05 & 914.77 \\
2050 & 1015.69 & 934.55 & 921.79 & 916.84 \\
Deficit & 114.18 & 33.04 & 20.28 & 15.33 \\
\hline
\end{tabular}

5. Implementing and enhancing the sharing and cooperation of the different water users for integrated management of future water demand.

Acknowledgments This project was supported financially by the Science and Technology Development Fund (STDF), Egypt, Grant No 1886 US-Egypt Program. 


\section{References}

Abdin AE, Gaafar I (2009) Egyptian water policies towards increasing its value, paper presented at MELIA workshop, Istanbul 21-23 March 2009

Abdin AE, Afify A, Adel A (2011) Comparative analysis of Egyptian water policy and water framework directive. Options Mediterrannées, A $\mathrm{n}^{\circ}$ 98, 2011-dialogues on Mediterranean water challenges: rational water use, water price versus value and lessons learned from the European Water Framework Directive

Abou Hussein SD, Sawan OM (2010) The utilization of agricultural waste as one of the environmental issues in Egypt (a case study). J App Sci Res 6(8):1116-1124

Abraham G, Bakr A (2000) Comprehensive development plan for the City of Luxor, Egypt-Investment project\#4, Investment portfolio for the development of infrastructure serving New Luxor and El Toad. Abt Associates Inc

Abraham G, Bakr A, Lane J (2000) The comprehensive development of the City of Luxor project, Egypt-Final structure plan, vol 2. Supplementary documents. Abt Associates Inc

Abu-Zeid M (1991) Water resources assessment for Egypt. Ministry of Water Resources and Irrigation, Egypt

Abu-Zeid M (1995) Major policies and programs for irrigation drainage and water resources development in Egypt. Options Mediterranéennes, Sér. B/no 9, Egyptian Agricultural Profile

Abu-Zeid M (1997) Egypt's water policy for the 21st century, IXth World Water Congress of IWRA, a special session on water management under scarcity conditions: the Egyptian experience, Montreal, Canada, Sept 1997

Abu-Zeid M, El-Shibini FZ (1997) Egypt's high aswan dam. Water Res Dev 13(2):209-217

Ahmed AA (2003) The impact of hydrogeological conditions on the archaeological sites at some localities between Qena and Aswan, Egypt. Ph. D. Thesis, Geology Department, Faculty of Science, South Valley University, Sohag, Egypt

Ahmed AA (2009) Using generic and pesticide DRASTIC GIS-based models for vulnerability assessment of the Quaternary aquifer at Sohag, Egypt. Hydrogeol J 17(5):1203-1217

Ahmed AA (2013) Fluoride in Quaternary groundwater aquifer, Nile Valley, Luxor, Egypt. Arabian J Geosci 1-15

Ahmed AA, Ali MH (2011) Hydrochemical evolution and variation of groundwater and its environmental impact at Sohag, Egypt. Arabian J Geosci 4(3-4):339-352

Allen RG (2003) Crop coefficients. Encyclopedia of water Science. doi:10.1081/E-EWS120010037

Allen RG, Pereira LS, Raes D, Smith M (1998) Crop evapotraspiration: guidelines for computing crop water requirements. FAO irrigation and drainage, Paper No. 65. FAO, Rome, Italy, p 300

Allen RG, Pereira LS, Smith M, Raes D, Wright JL (2005) FAO-56 dual crop coefficient method for estimating evaporation from soil and application extensions. ASCE 131(1):2-13. doi:10.1061/ (ASCE)0733-9437

Aly AA (2007) Managing water in a sustainable manner. Eleventh International Water Technology Conference, IWTC11 2007 Sharm El-Sheikh, Egypt

Awad MA, El Arabi NE, Hamza MS (1997) Use of solute chemistry and isotopes to identify sources of groundwater recharge in the Nile Aquifer Sysytem, Upper Egypt. Ground Water 35(2):223-226

Baines J, and Malek J (2000) Cultural atlas of ancient Egypt. Checkmark Books, Rev. Ed., p 240

Barber W, Carr DP (1981) Water management capabilities of the alluvial aquifer system of the Nile Valley, Upper Egypt. Technical Report No. 11, Water Master Plan, Ministry of Irrigation, Cairo
Brikowski TH, Faid A (2006) Pathline-calibrated groundwater flow models of Nile Valley aquifers, Esna, Upper Egypt. J Hydrol 324:195-209

Burman RD, Nixon PR, Wright JL, Pruitt WO (1980a) Water requirements, In: Jensen ME (ed), Design of farm irrigation systems, ASAE Mono, Am Soc Agric Eng, St. Joseph, MI, 189-232

Burman RD, Wright JL, Nixon PR, Hill RW (1980b) Irrigation management-water requirements and water balance. In: Irrigation, Challenges of the 80s, Proc. of the Second National Irrigation Symposium, Am Soc Agric Eng, St. Joseph, MI, $141-153$

CAPMAS (Central Agency for Public Mobilization and Statistics), Egypt (2006c) Preliminary results of general census of population, housing and establishments, Egypt, p 142, March 2007

CAPMAS (Central Agency for Public Mobilization and Statistics), Egypt (2006a) quarterly bulletin of industrial production, Ref 68-12600/2005

CAPMAS (Central Agency for Public Mobilization and Statistics), Egypt (2006b) quarterly bulletin of industrial production, Ref 65-12600/2006

CAPMAS (Central Agency for Public Mobilization and Statistics), Egypt (2007d) bulletin of water collection, refining and distribution

CAPMAS (Central Agency for Public Mobilization and Statistics), Egypt (2007a) quarterly bulletin of industrial production, Ref 66-12600/2006

CAPMAS (Central Agency for Public Mobilization and Statistics), Egypt (2007b) quarterly bulletin of industrial production, Ref 67-12600/2006

CAPMAS (Central Agency for Public Mobilization and Statistics), Egypt $(2007 \mathrm{c})$ quarterly bulletin of industrial production, Ref $65-12600 / 2007$

CAPMAS (Central Agency for Public Mobilization and Statistics), Egypt (2012) Population census database, Refs no. 1-212, $71-12511, \quad 135-0135 / 11 / 77, \quad 71-12511 / 78, \quad 71-12511 / 79$, $71-12511 / 80, \quad 71-12511 / 81, \quad 71 / 15211 / 82, \quad 71 / 14511 / 88$, 71-12511/84, 1977, 1980, 1981, 71-12511/1995, 1987, 71-12511/94, 1989, 71-12511/90, 71-12511/91, 71-12511/92, 1993, 1994, 71-12511/98, 71-12511/97, 71-12511/99, 71-12511/ 2000, 71-12511/98, 2006

CAPMAS (Central Agency for Public Mobilization and Statistics), Egypt (2013) Number of tourists and nights

CEDARE (2011) Water use efficiency and economic approachNational study Egypt. Plan Bleu UNEP/MAP Regional Activity Centre

Charalambous K, Bruggeman A, Lange MA (2012) The impact of climate change on water use in the tourism sector of Cyprus. Energy, environment and water research centre, The Cyprus Institute, Nicosia

Crush J (1995) Power of development. Jonathan crush and contributors, New York, p 323

Doorenbos J, Kassam AH (1979) Yield response to water. FAO irrigation and drainage paper No. 33, FAO, Rome, Italy, p 193

Doorenbos J, Pruitt W (1975) Guidelines for predicting crop water requirements, irrigation and drainage Paper no. 24, FAO-ONU, Rome, Italy, p 168

Doorenbos J, Pruitt W (1977) Crop evapotranspiration. FAO irrigation and drainage Paper 24. p 180

Dowdy S, Weardon S, Chilko D (2004) Statistics for research. 3rd edn. Wiley Inc. Publication, New York

EEAA "Ministry of State for Environmental Affairs, Egypt" (2005) Qena Governorate Environmental Action Plan. Egyptian Environmental Affairs Agency, SEAM Programme, Entec UK Ltd., ERM 
El Tahlawi M, Farrag A, Ahmed S (2008) Groundwater of Egypt: "an environmental overview". Environ Geol 55(3):639-652

El-Nahrawy MA (2011) Country pasture/forage resource profilesEgypt. FAO

El-Nahry AH, Doluschitz R (2010) Climate change and its impacts on the coastal zone of the Nile Delta, Egypt. Environ Earth Sci 59(7):1497-1506

Elwaseif M, Ismail A, Abdalla M, Abdel-Rahman M, Hafez M (2012) Geophysical and hydrological investigations at the west bank of Nile River (Luxor, Egypt). Environ Earth Sci 67(3):911-921

FAO (1992) CROPWAT, a computer program for irrigation planning and management by M. Smith. FAO irrigation and drainage paper No. 26. Rome

FAO (1995) Irrigation in Africa in figures, water reports No. 7, Rome, FAO

FAO (1998) Irrigation and Drainage Series No. 56 "Crop evapotranspiration-guidelines for computing crop water requirements" and No. 33 titled "Yield response to water"

Farrag AA (1982) Hydrogeological studies on the quaternary waterbearing sediments in the area between Assiut and Aswan. M.Sc. Thesis. Geol Dept., Assiut Univ., Egypt

Hegazi AM, El Bagouri IH (2002) National action plan for combating desertification, provisional. Arab Republic of Egypt, p 41

Rosenzweig C, Hillel, D (1994) Egyptian agriculture in the 21st Century. IIASA, CP-94-12

Ibrahim MT (1996) The dimensions of arid climate of the Nile Valley and its effects on human activity. M.Sc. Thesis, Geography Department, Faculty of Arts, South Valley University, Sohag, Egypt

Ismail A, Anderson NL, Rogers JD (2005) Hydrogeophysical Investigation at Luxor, Southern Egypt. JEEG 10(1):35-49

Johnson RA, Bhattacharyya GK (2010) Statistics-principles and methods. 6th edn. Wiley, Inc, New York

Johnson R, Kuby P (2012) Elementary statistics, 11th edn. Cengage Learning, Brooks/Cole

Kamel ER (2004) Geology of Luxor area and its relationship to groundwater uprising under the Pharaohs Temples. M. Sc. Thesis, Aswan Faculty of Science, South Valley University, Egypt

Klitzsch E, Wycisk P (1987) Geology of the sedimentary basins of Northern Sudan and bordering areas. Berl Geowiss Abh A 75(1):97-136

Lamei A (2009) A technical economic model for integrated water resources management in tourism dependent arid coastal regions; the case of Sharm El Sheikh, Egypt

MALR (2000) Mubarak national scheme for settling and developing newly reclaimed lands. Publication from the Ministry of Agriculture and Land Reclamation, Egypt

MALR (2003) Information on the size of public land reclamation by the Ministry of Agriculture and Land Reclamation, Egypt, compiled by Kheiry Sherif, Ministry of Agriculture and Land Reclamation, Egypt

MALR (2012) Crops cultivated at Luxor Governorate. Ministry of Agriculture and Land Reclamation, Egypt

McCarl BA, Musumba M, Smith JB, Kirshen P, Jones R, El-Ganzori A, Ali MA, Kotb M, El-Shinnawy I, El-Agizy M (2013) Climate change vulnerability and adaptation strategies in Egypt's agricultural sector. Mitigation and Adaptation Strategies for Global Change 1-13

MHUUD "Ministry of Housing, Utilities and Urban Development, Egypt" (2007) Luxor database, Governorate information and Decision support Center

MI "Ministry of Interior, Egypt" (2008) Total number of tourists in Egypt and Luxor, 1994-2008. General Department of Tourism and Antiquities Police
Nasr ML (1997) Social dimensions of the policy of the use of water. Options Méditerranéennes, SéE A/n031, 1997 Séminaires Méditerranéens

Nassar A, El-Korashey R (2003) Sustainable development and reuse of wastewater. Seventh International Water Technology Conference Egypt 1-3 April 2003

RIGW "Research Institute for Groundwater, Egypt" (1997) Hydrogeological maps of Egypt, scale 1:100,000. Water Research Center, Ministry of Public Works and Water Resources, Egypt

RIGW/IWACO (1997) Water quality monitoring programme (TN/ 70.00067/WQM/97/20)

Said R (1981) The geological evolution of the River Nile. Springer, New York Inc, p 151

Sallam GA (2003) Quality control and quality assurance of subsurface drainage Projects in Egypt. Diffuse Pollution Conference Dublin 2003:3-149

Salman SM (2010) Water resources in the Sudan North-South peace process: past experience and future Trends. African Foundation for International Law, Yusuf AA (ed) African Yearbook of International Law, 299-328

Shahin M (1991) Assessment of groundwater resources in Egypt. IHE Report Series no. 23. The Netherlands: international institute for hydraulic and environmental engineering

Shamrukh M, Abdel-Wahab A (2008) Riverbank filtration for sustainable water supply: application to a large-scale facility on the Nile River. Clean Techn Environ Policy 10:351-358. doi:10.1007/s10098-007-0143-2

Shamrukh M, Corapcioglu MY, Hassona FA (2001) Modeling the effect of chemical fertilizers on groundwater quality in the Nile Valley aquifer, Egypt. 39(1):59-67, Groundwater-January-February 2001

Smith M (1992) CROPWAT. A computer program for irrigation planning and management. Irrig Drain Paper 46, FAO, Rome

Smith M (1993) CLIMAT for CROPWAT. A climatic database for irrigation planning and management. Irrig Drain Paper 49, FAO, Rome

SPSS Inc. (2007) SPSS advanced statistics 17. SPSS Inc., USA

Indexmundi (2013) Egypt-international tourism, number of arrivals. http://www.indexmundi.com/facts/egypt/international-tourism

Lanquar R (2011) Tourism in the Mediterranean: scenarios up to 2030. Mediterranean prospects, Uropean Commision, p 44

Rady A (2002) Tourism and sustainable development in Egypt. Plan Blue, $\mathrm{p} 47$

Tucson AZ (2005) ReliaSoft Corporation, life data analysis reference, ReliaSoft Publishing

Tyson P (2010) Sunshine guide to Luxor and the Valley of the Kings, www.climates.com

UNWTO (2013) Tourism highlights. World Tourism Organization, p 16

Walpole RE, Myers RH, Myers SL, Ye K (2007) Probability and statistics for engineers and scientists. 8th edn. Pearson Education International

Wendorf F, Schild R (2002) Implications of incipient social complexity in the Late Neolithic in Egyptian Sahara. In Egypt and Nubia: gifts of the desert, Friedman R (ed), London, 13-20

World Gazetteer- Egypt (2010) Egypt: largest cities and towns and statistics of their population (retrieved 27 July 2010), http:// www.world-gazetteer.com

Zhiming F, Dengwei L, Yuehong Z (2007) Water requirements and irrigation scheduling of spring maize using GIS and CropWat model in Beijing-Tianjin-Hebei region. Chinese Geogr Sci 17(1):056-063. doi:10.1007/s11769-007-0056-3 